\title{
Anti-Oxidant Protective Effects of Cassia Alata in Rats Exposed to Carbon Tetrachloride
}

\author{
${ }^{1,{ }^{*} W E G W U, ~ M ~ O ; ~ A Y A L O G U, ~ E ~ O ; ~}{ }^{2}$ SULE, O J \\ 'Department of Biochemistry, University of Port Harcourt. P.M.B 5323, Port Harcourt E-mail: wevic2000@yyahoo.com
}

2Departments of Medical Biochemistry, Niger Delta UniversityWilberforce Island, Bayelsa State

\begin{abstract}
The protective activity of Cassia alata against carbon tetrachloride $\left(\mathrm{CCl}_{4}\right)$ - induced hepatotoxicity in rats was assessed. Crude extracts of petals of the plant in $0.5 \%$ ethanol were administered by intubation for 14

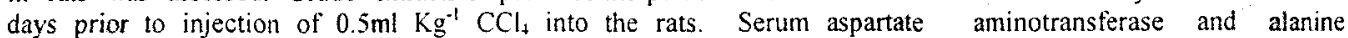
aminotransferase levels, 18 hours after $\mathrm{CCl}_{4}$ administration, decreased significantly $(P \leq 0.05)$ in rats treated with the extracts than in $\mathrm{CCl}_{4}$ - treated rats only. These findings suggest that Cassia_alata may be protective against hepatotoxin-induced liver damage in rats. @JASEM
\end{abstract}

A number of chemicals, including $\mathrm{CCl}_{4}$ are known to cause necrosis of cell or tissue. The damage or death of tissue usually results in the leakage of the enzymes in the affected tissue(s) into the blood stream (Sieger et. al., 1985; Obi et. al., 2001). Serum or plasma enzyme levels have been used as markers for monitoring chemically induced tissue damages (Lin and Wang, 1986; Ngaha et. al., 1989). The enzymes L-Alanine aminotransferase (L-ALT) [E.C. 2.6.1.2] and L-Aspartate aminotransferase (L-AST) [E.C. 2.6.1.1] are important enzymes that are often employed in assessing liver injury (Jaeger et al., 1975; Ngaha et. al., 1989; Obi et. al., 1998). The biotransformation of $\mathrm{CCl}_{4}$ to metabolites is a cytochrome $\mathrm{P} 450$-mediated reaction that initiate lipid peroxidation and attendant tissue damage. Shenoy et al (2001) reported that the oxidative camage through free radical generation is among the various mechanisms involved in the hepatotoxic effects of $\mathrm{CCl}_{4}$.

Some plant extracts have been shown to have protective antioxidant effects and are therefore hepatoprotective. Such plants would include $H$. rosasinensis (Obi et. al., 1998), Celosia argentea (Koji et. al., 1996), Ginkgo biboba (Shenoy et al., 2001), among others. Cassia alata, a soft wooden plant, common in villages and clearings within the Delta zone of Nigeria has been reported by Elenwo (1997) to have some antimicrobial properties. The leaves and stem bark are taken orally after maceration and filteration for the treatment of heart burn, in some localities (Elenwo, 1997). The flowers and leaves are used for the treatment of ringworms and eczema.
This study was therefore designed to evaluate the anti-oxidant protective effects of Cassia alata in rats exposed to carbon tetrachloride $\left(\mathrm{CCl}_{4}\right)$.

\section{MATERIALS AND METHODS}

Animals: Twenty adult male Wistar albino rats $(200-250 \mathrm{~g})$ used in this study were obtained from the Animal House, Department of Biochemistry, University of Port Harcourt, Port Harcourt, Nigeria. They were housed in standard cages (Griffin and George Modular Cage System) and left to acclimatize for 7-days to laboratofy conditions before the commencement of the experiment. During the acclimatization, the animals were fed with pelleted rat chow and water ad libitum.

Chemicals: Absolute ethanol and formic acid were the products of $\mathrm{BDH}$ Chemical Company Ltd (Poole, England) while $\mathrm{CCl}_{4}$ and chloroform were from May and Baker (Dagenham, England). Other materials include vegetable oil (Mazola produced for $\mathrm{CPC}, \mathrm{UK}$ ) and rat chow (Pfizer Nigeria Plc).

Preparation of extracts. The petals of Cassia alata were collected from Omuhuechi, Aluu in Rivers State, Nigeria. Preparation of the extracts followed the method of Obi et. al. (1998). $50 \mathrm{~g}$ of petals of the plant were macerated in a mortar and introduced into a $250 \mathrm{ml}$ beaker. Initial extraction was achieved using $150 \mathrm{ml}$ of formic acid, ethanol, water (1:10:9 $\mathrm{v} / \mathrm{v} / \mathrm{v})$ mixture. The extract was filtered after three hours through cheese cloth. This was repeated thrice and the filtrates were pooled. An equal volume of petroleum ether (bp $40-60^{\circ} \mathrm{C}$ ) was employed in the 'washing' of the pooled filtrate in a separatory funnel. The separatory funnel and its content was shaken vigorously (manually at $5 \mathrm{~min}$. 
intervals) for 2 hours and allowed to stand for 12 hours in order to eliminate carotenoids and chlorophyll from the extract. The washed extract was left at $4^{\circ} \mathrm{C}$ while the petroleum ether layer was discarded. The organic solvents were evaporated at $70^{\circ} \mathrm{C}$ using low temperature hot plate (B\&T, Searle Company) and the residue filtered through a 0.45 micron filter paper using a vacuum pump (Compach). The concentrate was mixed with $5 \%(\mathrm{v} / \mathrm{v})$ ethanol and left at $4^{\circ} \mathrm{C}$ in a refrigerator until used.

Experimental Procedure: The rats were divided into five experimental groups with each consisting of four rats. Rats in groups 1 and 2 received $2.5 \mathrm{ml} / \mathrm{kg}$ body weight of $5 \%(\mathrm{v} / \mathrm{v})$ aqueous ethanol by gavage. The rats in groups 3,4 and 5 were given $2.5 \mathrm{ml} / \mathrm{kg}$ body weight of $1.0,5.0$ and $10.0 \%$ $(v / v)$ solution of the crude extract concentrate in aqueous ethanol, respectively, by gavage. These treatments were for 14 days. $\mathrm{CCl}_{4}$ dissolved in vegetable oil was administered intraperitoneally to rats in groups $2,3,4$ and 5 at a dose of $0.5 \mathrm{ml} / \mathrm{kg}$ body weight in $0.5 \mathrm{ml}$ of vegetable oil on the $14^{\text {th }}$ day, after the administration of the extracts of Cassia alata. The rats in group 1 received $0.5 \mathrm{ml}$ of vegetable oil only intraperitoneally. Eighteen hours after the administration of $\mathrm{CCl}_{4}$, the rats were anaesthetized in a chloroform saturated chamber. Blood samples were obtained by cardiac puncture from each rat by means of a $5 \mathrm{ml}$ hypodermic syringe and needle and placed in an anticoagulant free bottle.

The serum was used for the assay of the hepatic enzymes activities (L-AST and L-ALT) using the Humazym MUV-test kits. The mean values of the control and test serum activities of a given enzyme were compared using the student's t-test (Zar, 1984). The significance level was set at $P \leq 0.05$.

\section{RESULTS AND DISCUSSION}

Serum L-AST and L-ALT induced by $\mathrm{CCl}_{4}$ treatment and the effects of treatment with various concentrations of extracts of Cassia alata prior to treatment of rats with $\mathrm{CCl}_{4}$ are shown in Tables 1 and 2 , respectively. In the rats treated with $\mathrm{CCl}_{4}$ only, there was a significant $(\mathrm{P} \leq 0.05)$ increase in the activities of the enzymes. A concentration-dependent decrease $(P \leq 0.05)$ in the activities of both L-ALT and L-AST was observed in rats pretreated with extracts of Cassia alata prior to administration of $\mathrm{CCl}_{4}$ compared with $\mathrm{CCl}_{4}$ - treated rats alone. There was no significant difference $(P \leq 0.05)$ in the activities of the enzymes in the control rats (Group 1) with those that received $10 \%$ extract with $\mathrm{CCl}_{4}$ treatment (Group 5) for L-ALT. A similar trend was observed for LAST in rats in Group 4 (5.0\% extract) and Group 5 (10\% extract).

Table 1. Effects of crude extracts of Cassia alata on serum L-ALT activity (U///mean mg protein) in $\mathrm{CCl}_{4}$ - induced liver damage

\begin{tabular}{|c|c|c|c|c|}
\hline GROUP & $\mathrm{CCl}_{+} \mathrm{ml} / \mathrm{kg}$ & EXTRACT $(\%)$ & MEAN & S.E.M \\
\hline 1. & - & - & $102.06^{\mathrm{a}}$ & 1.01 \\
\hline 2. & 0.5 & - & $213.75^{\circ}$ & 1.32 \\
\hline 3. & 0.5 & 1.0 & $1+3.39^{c}$ & 1.53 \\
\hline 4. & 0.5 & 5.0 & $119.29^{d}$ & 1.34 \\
\hline 5. & 0.5 & 10.0 & $109.72^{a}$ & 0.52 \\
\hline
\end{tabular}

One commonly used hepatotoxin in the experimental study of liver diseases is $\mathrm{CCL}_{4}(\mathrm{Koji}$ et. al., 1996; Obi et. al., 1998; Shenoy et al., 2001). The toxicity of $\mathrm{CCl}_{4}$ to the liver of mammals is largely as a result of the active metabolite, trichloromethyl radical (Johnston and Kruening, 1998). The trichloromethyl radical binds to tissue macromolecules and thus induce peroxidative degradation of membrane lipids of the endoplasmic reticulum which are rich in polyunsaturated fatty acids. Shenoy et. al. (2001) postulated that such development would ultimately lead to the formation of lipid peroxides that in turn yield other products, among which is malondialdehyde (MDA). MDA has been demonstrated to cause damage to the membrane. Hence, one of the principal causes of hepatotoxicity of $\mathrm{CCl}_{4}$ is the lipid peroxidative degradation of biological membrane (Kaplowitz et al., 1986; Cotram et. al., 1994).

Our preliminary investigations on the toxicity of CCL4 in male wistar albino rats indicate that administration of $\mathrm{CCL} 4$ concentrations above 0.6 $\mathrm{mg} / \mathrm{kg}$ was lethal within 24-hours. Also CCL4 levels

WEGWU, MO;AYALOGU, EO; SULE, OJ 
below $0.4 \mathrm{mg} / \mathrm{kg}$ was not lethal and liver damage was not obvious. These findings informed the application of $0.5 \mathrm{mg} / \mathrm{kg}$ in this study to induce liver damage in rats. The CCL4 dose adopted in this work is in agreement with that of Obi et.al.(1998) who induced liver damage in rats by administering CCL4 levels of $0.5 \mathrm{mg} / \mathrm{kg}$

Table 2 Effect of crude extracts of Cassia alata on serum L-AST activity (U/1/mean mg protein) in $\mathrm{CCl}_{4}$ - induced liver damage

\begin{tabular}{ccccc}
\hline GROUP & $\mathrm{CCl}_{+} \mathrm{ml} / \mathrm{kg}$ & EXTRACT $(\%)$ & MEAN & S.E.M \\
\hline 1. & - & - & $107.26^{\mathrm{a}}$ & 1.04 \\
2. & 0.5 & - & $227.32^{\circ}$ & 1.53 \\
3. & 0.5 & 1.0 & $140.38^{\circ}$ & 1.30 \\
4. & 0.5 & 5.0 & $116.44^{\circ}$ & 1.03 \\
5. & 0.5 & 10.0 & $110.75^{\mathrm{a}}$ & 2.08 \\
\hline Means with different superscripts are significantly different at the 0.05 & level \\
& Values are means for 4 replicates $(\mathrm{n}=4)$ \\
& S.E.M = standard error of the mean.
\end{tabular}

The results in this study indicate that $\mathrm{CCl}_{4}$ caused an increase in the serum levels of marker enzymes: ALT and AST. Such elevation is indicative of liver injury, especially, the rise in L-ALT activity (Lin and Wang, 1986; Reinke et. al., 1988). The injection of $0.25 \mathrm{ml}$ of $1.0,5.0$ and $10.0 \%$ crude extracts / $\mathrm{kg}$ body weight of rats for 14 days prior to administration of $0.5 \mathrm{ml} / \mathrm{kg} \quad \mathrm{CCl}_{4}$ progressively caused a decline in hepatotoxicity than with $\mathrm{CCl}_{4}$ alone. This is evidenced in the marked decrease in serum L-AST and L-ALT activity relative to the group treated with $\mathrm{CCl}_{4}$ only. Shenoy et. al. (2001) reported an elevation in the levels of MDA in liver of rats treated with $\mathrm{CCl}_{4}$ only. They attributed the increase in MDA levels to enhanced lipid peroxidation, leading to tissue damage and failure of antioxidant defence mechanisms to prevent the formation of excessive free radicals. The results in this study suggest that pretreatment of rats for 14 days with Cassia alata prior to $\mathrm{CCl}_{4}$ administration significantly $(\mathrm{P} \leq 0.05)$ reversed these changes. It would be deduced, therefore, that the antioxidant effects of crude extracts of Cassia alata could possibly be its mechanism of hepatoprotection.

In order to eliminate contamination with lipids, including lipid soluble materials, $50 \%$ aqueous ethanol slightly acidified with formic acid was employed in anthocyanin extraction present in the Cassia alata (Obi et al., 1998). The extraction condition reported in this work ensured that the carotenes, tocopherols, chlorophyll, carotenoids, sterols, aglycones and catecols (Ibrahim and Baron, 1989; Van Sumere, 1989) were not present in the extract. Therefore, the anti-oxidant that is present in the extract is anthocyanin. This is in agreement with Obi et al. (1998) who reported the protection of $H$. rosasinensis anthocyanin against $\mathrm{CCl}_{4}$-induced liver damage in rats. The anthocyanin in the extract may have prevented liver damage by breaking the sequence of events between the reductive dechlorination of $\mathrm{CCl}_{4}$; abstraction of hydrogen ion from unsaturated fatty acids in the membrane; and peroxide formation. The anthocyanin may also have inhibited the activities of cytochrome $P_{450}$ Isoenzymes required for trichloromethyl radical production

Appreciation: The authors wish to express their profound gratitude to the University of Port Harcourt for the Senate Research Grant No UPH/DVC.AC/11/SD.022/COM.4 in partial support for this work.

\section{REFERENCES}

Contram, R. S., Kumar, V: and Robbins, S. L (1994). Cell injury and cellular death. In Robbin's Pathologic Basis of Diseases. $5^{\text {th }}$ ed. Prism Book Pvt. Ltd. 379-430.

Elenwo, E.N.(1997). Effectiveness of leaves of $C$. alata and Vernonia myadalina in the preservation of Okra fruits in the Niger Delta. Nig. Journ. Crop, Soil and Forestry. 3: 5-9.

Ibrahim, R., Baron, D.(1989). Phenylpropanoids. In: Dey, P.M.., Harborne, J.B.(E.ds), Methods in Plant Biochemistry.Vol.1, Plant Phenolics. Academic Press, London, pp. 75-111.

Jaeger, R.J., Conolly, R.B., Murphy, S.D.(1975). Short term inhalation toxicity of halogeneted hydrocarbon. Arch. Environ Health. 30:26-31.

Johnston, D.E., Kroening, C.(1998). Mechanism of early $\mathrm{CCl} 4$ toxicity in cultured rat hepatocytes. Pharmacol Toxicol. 83:231-39. 
Kaplowitz, N., Simon, F.R., Stolz A.(1986). Druginduced hepatotoxicity. Ann. Int. Med. 104:82639.

Koji, H., Shigotohi, K., Purusotam, B., Tsuneo,N. (1996). Hepatoprotective effects of traditional medicines. Isolation of the active constituent from seeds of $C$. argentea. Phytotherapy Research. 10:387-392.

Lin, J.K., Wang, C.J.(1986). Protection of crocin dyes in the acute hepatic damage induced by Aflatoxin $B_{1}$, and dimethylnitrosamine in rats. Carcinogenesis 7:595-599.

Ngaha, E.O.., Akanji, M.A., Madusolumuo, M.A. (1989). Studies on correlation between chloroquine induced tissue damage and serum enzyme changes in the rat. Experientia 45: 143 146.

Obi, F.O., Usenu I.A., Osayande, J.O. (1998). Prevention of $\mathrm{CCl}_{4}$-induced hepatotocxicity in the rat by $\underline{H}$. rosasinensis anthocyanin extract administered in ethanol. Toxicol 131: 93-98.

Obi F.O., Omogbai, L.A., Oriafo, O.S.J., Ovat, O. D. (2001). Effect of a short time post $\mathrm{CCl}_{4}$ treatment interval on rat plasma enzyme levels and percentage mortality. J. Appl. Sci. Environ. Mgt. $6(1): 5-8$.

Reinke, L.A., Lia, E.K. McCay, P.B. (1988). Ethanol feeding stimulates trichloromethyl radical formation from $\mathrm{CCL}_{4}$ in liver. Xenobiotica 18:1311-1318.

Van Sumere, C. F. (1989). Phenols and Phenolic Acids. In: Dey, P.M.., Harborne, J.B.(E.ds), Methods in Plant Biochemistry.Vol.1, Plant Phenolics. Academic Press, London, pp. 29 -73 .

Shenoy, K.A., Somayaji, S.N., Bairy, K.L.(2001). Hepatoprotective effects of Ginkgo biloba against $\mathrm{CCL}_{4}$ - induced hepatic injury in rats Indian J. Pharmacol. 33: 260-266.

Siegers, C.P., Horn, W., Younes, M.(1985). Effects of hypoxia on the metabolism and hepatotoxicity of $\mathrm{CCl}_{4}$ and vinylidene chloride in rats. Acta Pharmacol. Toxicol. 56: 81-86.

Zar, J.H. (1984). Biostatiscal Analysis. Prentice Hall, Eaglewood Cliffs, N. J. USA. pp 21-34. 